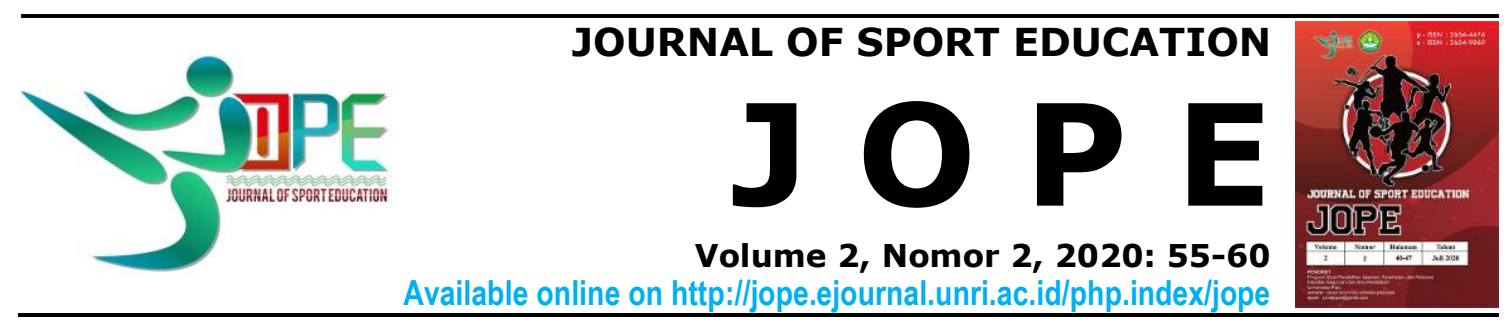

\title{
Pengaruh latihan variasi terhadap kemampuan servis atas bolavoli pada mahasiswi putri unit kegiatan mahasiswa penjaskesrek
}

\author{
Nova Risma ${ }^{1}$, Rices Jatra ${ }^{2}$ \\ ${ }^{1,2}$ Fakultas Keguruan dan Ilmu Pendidikan, Universitas Islam Riau \\ Novarisma@edu.co.id ${ }^{1}$, ricesjatra@edu.co.id ${ }^{2}$
}

Received: 20 Februari 2020; Revised 29 Maret 2020; Accepted 29 Maret 2020

doi http://dx.doi.org/10.31258/jope.2.2.55-60

\begin{abstract}
Abstrak
Tujuan penelitian ini untuk mengetahui pengaruh latihan variasi terhadap kemampuan servis atas bolavoli. Jenis penelitian ini eksperimen semu (Quasi Experimen). Sampel dalam penelitian ini yaitu pemain bolavoli putri UKM Universitas Islam Riau yang berjumlah 20 orang. Penarikan Sampel dalam penelitian ini menggunakan teknik sampel jenuh. Instrument tes yang digunakan dalam penelitian ini yaitu tes servis atas bolavoli. Analisis data yang digunakan yaitu uji $\mathrm{t}$ dengan $\alpha=0,05$. Hasil penelitian ini menunjukkan bahwa latihan variasi memberikan pengaruh yang signifikan terhadap kemampuan servis atas bolavoli mahasiswi Unit Kegiatan Mahasiswa Penjaskesrek Universitas Islam Riau dan terjadi peningkatan skor rata-rata sebesar 6,2 .
\end{abstract}

Kata Kunci: latihan variasi, servis, bolavoli

The effect of variation training on the ability to serve volleyball in female students of the penjaskesrek student activity unit

\begin{abstract}
The purpose of this study was to determine the effect of variation training on service ability for volleyball. The type of research is quasi experimental. The sample in this study were 20 female volleyball players from the Riau Islamic University. Sampling in this study uses a saturated sample technique. The test instrument used in this study is the service test for volleyball. Analisys of the data used is the t test $\alpha=0,05$. The result of study showed that variation training had a significant influence on the ability to service the volleyball of female student units of the riau Islamic university and an increase in the average score of 6,2.
\end{abstract}

Keywords: variation exercise, service, volleyball

How To Cite: Risma, Nova \& Jatra, Rices. (2020). Pengaruh latihan variasi terhadap kemampuan servis atas bolavoli pada mahasiswi putri unit kegiatan mahasiswa penjaskesrek. Journal of Sport Education (JOPE), 2 (2), 55-60.

\section{PENDAHULUAN}

Permainan bolavoli merupakan permainan yang dimainkan oleh 2 tim yang masingmasing terdiri dari 6 orang pemain dan berlomba-lomba mencapai angka 25 terlebih dahulu. Dalam permainan bolavoli terdapat beberapa teknik dasar yang harus di kuasai oleh pemain, diantaranya adalah service, passing bawah, passing atas, smash, dan blocking. Hal tersebut perlu diperhatikan mengingat teknik dasar merupakan faktor penting dan berpengaruh 
Journal of Sport Education (JOPE), 2 (2) 2020 - 56

Nova Risma ${ }^{1}$, Rices Jatra ${ }^{2}$

serta dibutuhkan dalam permainan bolavoli

(Lardika \& Salam, 2019). Untuk memiliki

kemampuan teknik dasar yang baik seorang pemain bolavoli harus melakukan latihan secara rutin, terprogram dan berkesinambungan. Untuk mendapatkan kemampuan teknik dasar yang baik hanya dapat dilakukan dengan melakukan latihan, terprogram, dan berkesinambungan. Hal ini sesuai dengan apa yang disampaikan (Boreham, 2006) bahwa bahwa optimisasi penampilan merupakan hasil latihan dalam jangka waktu panjang dan terstruktur.

Variasi latihan sangatlah penting bagi para mahasiswa, didasarkan pada asumsi bahwa seorang mahasiswa akan dapat mengembangkan komponen-komponen dari semua unsur fisik antara lain kekuatan, daya tahan, kelincahan, kelenturan dan sebagainya. Senada dengan apa yang disampaikan (Pranopik, 2017) bahwa (1) atlet lebih termotivasi dalam melaksanakan program latihan karena adanya variasi latihan yang lebih banyak; (2) Atlet lebih termotivasi untuk mendapatkan variasivariasi latihan baru; (3) Atlet mendapatkan pengalaman variasi latihan yang lebih banyak sehingga memungkinkan membantu pada saat bertanding.

Berdasarkan observasi yang telah dilakukan pada tim bolavoli putri di Unit Kegiatan Mahasiswa (UKM) Universitas Islam Riau terlihat bahwa pemain bolavoli putri UKM Universitas Islam Riau masih memiliki fundamental atau tekhnik dasar permainan bolavoli yang kurang baik, salah satunya adalah keterampilan servis atas. Hal ni terlihat pada beberapa pertandingan yang dijalani oleh tim bolavoli putri UKM Universitas Islam Riau, tim bolavoli UKM Universitas Islam Riau hanya mampu meraih dua kali juara III di tahun 2018 pada tingkat perguruan tinggi. Kegagalan yang diperoleh tim bolavoli UKM Universitas Islam Riau terjadi pada kurang maksimalnya para pemain dalam melakukan servis pada saat akan memulai permainan, sehingga lawan dengan mudah untuk mengembalikan bola atau bahkan sampai membuat poin dengan mudah terhadap tim bolavoli putri UKM Universitas Islam Riau. Dalam pertandingan permaianan bola voli, servis merupakan salah satu bagian yang penting mengingat servis merupakan awal dari sebuah serangan dalam permainan bola voli (Buwana, 2017).

Untuk mendapatkan kemampuan servis atas yang baik tentunya banyak faktor yang mempengaruhinya seperti ayunan tangan pada saat melakukan servis atas, yang mengakibatkan tidak memberikan dorongan yang kuat pada saat melakukan servis atas. Kemudian saat melakukan servis atas, posisi kaki yang selalu bersamaan, seharusnya salah satu kaki berada di depan, sehingga dapat memberikan dorongan yang kuat pada saat melakukan servis atas. Disamping itu telapak tangan dikepal pada saat melakukan servis atas sehingga dorongan servis atas kurang baik, serta penempatan posisi tubuh baik pada saat penerimaan bola maupun pada saat pengembalian bola dalam permainan bolavoli terlihat kaku. Selain itu metode latihan yang digunakan dalam latihan juga 
Journal of Sport Education (JOPE), 2 (2) 2020 - 57

Nova Risma ${ }^{1}$, Rices Jatra ${ }^{2}$

sangat menentukan hasil latihan yang dicapai. Dalam sebuah penelitian juga disebutkan bahwa konsentrasi juga memiliki kontribusi yag tinggi terhadap ketepatan servis (Noerjannah \& Sudijandoko, 2016). Banyaknya pemberian metode dan variasi latihan akan dapat meningkatkan kemampuan servis atas. Saat melaksanakan pertandingan bola voli, sebaiknya para pemain melakukan servis atas untuk memulai sebuah permainan, hal ini dikarenakan servis atas tersebut biasanya sulit untuk dikembalikan oleh lawan jikalau servis yang diberikan kuat dan terarah. Terarah memiliki persamaan dengan ketepatan dalam mengarahkan bola. Dalam sebuah penelitian yang dilakukan oleh (Sovensi, 2018) didapatkan informasi bahwa kelentukan togok dan koordinasi mata tangan memiliki tingkat hubungan yang signifikan. Hasil Penelitian tersebut bisa dijadikan sebagai salah satu indikator untuk meningkatkan koordinasi mata tangan dan kelentukan togok melalui berbagai variasi latihan.

\section{METODE}

Tabel 1. Distribusi Frekuensi Data Tes Kemampuan Servis Atas

Kelompok Eksperimen

\begin{tabular}{ccccc}
\hline \multirow{2}{*}{ Kelas Interval } & \multicolumn{2}{c}{ Pre-test } & \multicolumn{2}{c}{ Post-test } \\
\cline { 2 - 5 } & Fa & Fr\% & Fa & Fr\% \\
\hline$>20$ & 0 & $0 \%$ & 8 & $80 \%$ \\
\hline $13-20$ & 10 & $100 \%$ & 2 & $20 \%$ \\
\hline $3-12$ & 0 & $0 \%$ & 0 & $0 \%$ \\
\hline$<3$ & 0 & $0 \%$ & 0 & $0 \%$ \\
\hline Jumlah & 10 & $100 \%$ & 10 & $100 \%$ \\
\hline
\end{tabular}

Berdasarkan tabel di atas dapat dilihat bahwa jumlah sampel penelitian yang berada pada kelas interval $>20$ sebanyak 0
Jenis penelitian ini adalah penelitian eksperimen semu (Quasi Experimen), yang bertujuan untuk menemukan ada tidaknya pengaruh perlakuan antara sebab dengan akibat antara variabel-variabel yang diteliti. Rancangan penelitian ini adalah two group pre test -post test yang terdiri dari dua kelompok penelitian yaitu: 1) Kelompok eksperimen (Kelompok Latihan Variasi) 2)

Kelompok Kontrol.

Penarikan Sampel dalam penelitian ini menggunakan teknik penarikan sampel jenuh. Sampel jenuh merupakan tekhnik penarikan sampel dengan cara sampel berasal dari seluruh populasi yang ada (Sugiyono, 2011:87).

Sebelum data dianalisis, terlebih dulu dilakukan uji persyaratan normalitas dan homogenitas. Untuk uji normalitas menggunakan uji Liliefors, sedangkan untuk uji homogenitas menggunakan uji $\mathrm{F}$. Data hasil tes keterampilan servis atas yang telah terkumpul dianalisis dengan menggunakan uji $\mathrm{t}$ dengan $\alpha=0,05$ Secara keseluruhan hasil uji hipotesis dalam penelitian ini dapat disajikan dalam

pembahasan sebagai berikut:

orang pada pre-test dan 3 orang pada posttest, pada kelas interval 13-20 sebanyak 10 orang pada pre-test dan 7 orang pada post- 
Journal of Sport Education (JOPE), 2 (2) 2020 - 58

Nova Risma ${ }^{1}$, Rices Jatra ${ }^{2}$

test, pada kelas interval 3-12 0 orang pada

selanjutnya pada kelas interval $<30$ orang

pre-test dan 0 orang pada post-test,

pada pre-test dan 0 orang pada post-test.

Tabel 2. Distribusi Frekuensi Data Tes Kemampuan Servis Atas

Kelompok Kontrol

\begin{tabular}{cccccc}
\hline \multirow{2}{*}{ Kelas Interval } & \multicolumn{2}{c}{ Pre-test } & \multicolumn{2}{c}{ Post-test } \\
\cline { 2 - 6 } & Fa & Fr\% & Fa & Fr\% \\
\hline$>20$ & 0 & $0 \%$ & 3 & $30 \%$ \\
\hline $13-20$ & 10 & $100 \%$ & 7 & $70 \%$ \\
\hline $3-12$ & 0 & $0 \%$ & 0 & $0 \%$ \\
\hline$<3$ & 0 & $0 \%$ & 0 & $0 \%$ \\
\hline Jumlah & 10 & $100 \%$ & 10 & $100 \%$ \\
Berdasarkan tabel di atas dapat & dilihat & orang pada pre-test dan 7 orang pada post- \\
berada pada kelas interval >20 sebanyak 0 & pre-test dan 0 orang pada post-test, \\
orang pada pre-test dan 3 orang pada post- & selanjutnya pada kelas interval <3 0 orang \\
test, pada kelas interval 13-20 sebanyak 10 & pada pre-test dan 0 orang pada post-test
\end{tabular}

Tabel 3. Uji Normalitas Data Penelitian Rangkuman Hasil

Uji Normalitas Data Penelitian

\begin{tabular}{lcccc}
\hline \multicolumn{1}{c}{ Uji Normalitas Data } & $\mathbf{N}$ & $\mathbf{L}_{\mathbf{0}}$ & $\mathbf{L}_{\mathbf{t}}$ & Ket. \\
\hline $\begin{array}{l}\text { Pre-test Kemampuan Servis Atas } \\
\text { Kelompok Eksperimen }\end{array}$ & 10 & 0,240 & 0,243 & $\begin{array}{c}\text { Berdistribusi } \\
\text { Normal }\end{array}$ \\
\hline $\begin{array}{l}\text { Post-test Kemampuan Servis Atas } \\
\text { Kelompok Eksperimen }\end{array}$ & 10 & 0,238 & 0,243 & $\begin{array}{c}\text { Berdistribusi } \\
\text { Normal }\end{array}$ \\
\hline $\begin{array}{l}\text { Pre-test Kemampuan Servis Atas } \\
\text { Kelompok Kontrol }\end{array}$ & 10 & 0,242 & 0,243 & $\begin{array}{c}\text { Berdistribusi } \\
\text { Normal }\end{array}$ \\
\hline $\begin{array}{l}\text { Post-test Kemampuan Servis Atas } \\
\text { Kelompok Kontrol }\end{array}$ & 10 & 0,239 & 0,243 & $\begin{array}{c}\text { Berdistribusi } \\
\text { Normal }\end{array}$ \\
\hline
\end{tabular}

Tabel 4. Uji Homogenitas Data Penelitian Rangkuman Hasil Uji

Homogenitas Data Penelitian

\begin{tabular}{lccl}
\hline \multicolumn{1}{c}{ Kelompok Penelitian } & $\mathbf{F}_{\mathbf{h}}$ & $\mathbf{F}_{\mathbf{t}}$ & \multicolumn{1}{c}{ Ket. } \\
\hline $\begin{array}{l}\text { Kemampuan Servis Atas Kelompok } \\
\text { Eksperimen }\end{array}$ & 1,05 & 2,79 & Homogen \\
\hline Kemampuan Servis Atas Kelompok Kontrol & 2,06 & 2,79 & Homogen \\
\hline
\end{tabular}

Tabel 5. Analisis Data Penelitian Rangkuman Hasil Analisis Data Penelitian

\begin{tabular}{lccc}
\hline \multicolumn{1}{c}{ Hipotesis } & $\mathbf{t}_{\mathbf{h}}$ & $\mathbf{t}_{\mathbf{t}}$ & Ket. \\
\hline $\begin{array}{l}\text { Kemampuan Servis Atas bolavoli mahasiswi UKM UIR kelompok } \\
\text { Latihan Variasi }\end{array}$ & 17,27 & 1,81 & Signifikan \\
\hline $\begin{array}{l}\text { Kemampuan Servis Atas bolavoli mahasiswi UKM UIR kelompok } \\
\text { Kontrol }\end{array}$ & 9,70 & 1,81 & Signifikan \\
\hline $\begin{array}{l}\text { Perbedaan Pengaruh Kemampuan Servis Atas bolavoli mahasiswi } \\
\text { UKM UIR kelompok Latihan Variasi dengan Kelompok Kontrol }\end{array}$ & 3,56 & 1,72 & Signifikan \\
\hline
\end{tabular}


Journal of Sport Education (JOPE), 2 (2) 2020 - 59

Nova Risma ${ }^{1}$, Rices Jatra ${ }^{2}$

\section{Pembahasan}

Berdasarkan hasil analisis data yang telah dilakukan, ditemukan bahwa latihan variasi memberikan pengaruh yang signifikan terahadap peningkatan kemampuan servis atas mahasiswi UKM UIR dimana $t_{h}(17,27)$ $>\mathrm{t}_{\mathrm{t}}(1,81)$ selain itu terjadi peningkatan rata-rata skor kemampuan servis atas pada kelompok latihan variasi dari 16,2 ke 22,4. Artinya terjadi peningkatan rata-rata kemampuan servis atas bolavoli mahasiswi UKM UIR sebesar 6,2.

Sehingga dapat disimpulkan bahwa latihan variasi efektif digunakan untuk meningkatkan kemampuan servis atas bolavoli mahasiswi UKM UIR. Menurut Irawadi (2011: 33) latihan variasi merupakan sebagai bentuk penyajian atau pelaksanaan kegiatan latihan dengan berbagai bentuk atau metode, gunanya untuk mencapai tujuan. Artinya untuk meraih suatu tujuan latihan, sebaiknya digunakan beberapa cara agar dalam latihan tidak timbul kebosanan. Selanjutnya Harsono (1998:121) mengemukakan bahwa di dalam variasi latihan dapat pula berbentuk permainan-permainan dengan bola, perlombaan-perlombaan estafet, berenang, naik sepeda ke gunung dan sebagainya. Pada penelitian lain oleh (Heriyanto, 2016) terkait pengaruh latihan variasi terhadap ketepatan shooting didapatkan hasil bahwa ada pengaruh yang signifikan dari pengaruh latihan variasi dengan menendang ke berbagai sasaran mengembangkan ketepatan shooting menggunakan punggung kaki.

Berdasarkan uraian di atas dapat disimpulkan bahwa latihan variasi adalah suatu bentuk latihan dengan metode atau cara penyajian pengajaran yang bermacammacam jenis metode, serta menimbulkan dan meningkatkan perhatian mahasiswa kepada aspek- aspek belajar mengajar yang relevan, memberikan kesempatan bagi berkembangnya bakat ingin mengetahui dan menyelidiki hal-hal yang baru dan untuk memupuk tingkah laku yang positif terhadap guru dan sekolah dengan berbagai cara mengajar yang lebih hidup dan lingkungan belajar yang lebih baik.

Selanjutnya Muhajir (2004:85) berpendapat beberapa prinsip penggunaan latihan variasi, adapun prinsip yang dimaksud adalah sebagai berikut:

1. Variasi hendaknya digunakan dengan sutu maksud tertentu yang relevan (sesuai) dengan tujuan yang hendak dicapai.

2. Variasi harus digunakan secara lancer dan berkesinambungan sehingga tidak akan merusak perhatian mahasiswa dan tidak menganggu pelajaran.

3. Direncanakan secara baik, dan dicantumkan dalam rencana pelajaran atau satuan pelajaran.

Berdasarkan pemaparan yang telah dikemukakan di atas, dapat disimpulkan bahwa latihan variasi sangat dibutuhkan pada saat menjalankan proses latihan. Hal ini bertujuan untuk menghilangkan kebosanan yang terjadi pada atlet. Sehingga diperlukan kejelian seorang pelatih ataupun guru untuk mencari variasi-variasi latihan yang dilakukan. Walaupun bolavoli 
Journal of Sport Education (JOPE), 2 (2) 2020 - 60

Nova Risma ${ }^{1}$, Rices Jatra ${ }^{2}$

merupakan salah satu cabang olahraga

Ketepatan Shooting Menggunakan

permainan akan tetapi variasi latihan tetap

Punggung Kaki Siswa Yang

dibutuhkan dalam bolavoli. Penelitian ini

telah memberikan bukti bahwa variasi

latihan sangat dibutuhkan bahkan pada

cabang olahraga permainan sekalipun.

\section{SIMPULAN}

Latihan variasi memberikan pengaruh yang signifikan terhadap kemampuan servis atas mahasiswi Unit Kegiatan Mahasiswa Penjaskesrek Universitas Islam Riau dimana $t_{h}(17,27)>t_{t}(1,81)$ dan terjadi peningkatan skor rata-rata sebesar 6,2.

Implementasi latihan variasi sangat dibutuhkan pada setiap cabang olahraga meskipun pada cabang olahraga permainan sekalipun. Hal ini bertujuan utuk menghilangkan kebosanan dan kejenuhan yang ditumbulkan pada saat latihan bagi seorang atlet.

\section{DAFTAR PUSTAKA}

Boreham, C. dkk. (2006). Advances In Sport and Exercise Science Series: The Physiology of Training. United Kingdom: Elsevier.

Buwana, I. P. W. T. (2017). I Putu Wira

Tresna Buwana Jurnal Ilmu K eolahragaan Undiksha. 6(1), 18-26.

Harsono. (1988). Coaching dan AspekPsikologis Dalam Coaching. Jakarta: Departemen Pendidikan dan Kebudayaan Direketorat Jenderal Pendidikan Tinggi.

Mengikuti Ekstrakurikuler Di Smp N 2 Depok Tahun 2016. Pendidikan Jasmani Kesehatan Dan Rekreasi, 1(5), 1-10.

Irawadi, H. (2011). Kondisi Fisik dan Pengukurannya. Padang. Jurusan Pendidikan Kepelatihan Olahraga FKIP Universitas Negeri Padang.

Lardika, R. A., \& Salam, S. (2019). Tinjauan Kemampuan Keterampilan Teknik Dasar Bola Voli pada Siswa Ekstrakurikuler Bola Voli Sman 1 Bunut. Journal Of Sport Education (JOPE), 2(1), 24-33. https://doi.org/10.31258/jope.2.1.2433

Muhajir. (2004). Pendidikan Jasmani Teori dan Praktek Jilid 1. Jakarta : Penerbit Erlangga.

Noerjannah, I., \& Sudijandoko, A. (2016). Kontribusi Konsentrasi terhadap Keterampilan Ketepatan Servis Atas Bolavoli pada Pemain Putri SMK Negeri 1 Kemlagi Mojokerto. Jurnal Kesehatan Olahraga, 5(2), 47-50.

Pranopik, M. R. (2017). Pengembangan Variasi Latihan Smash Bola Voli. Jurnal Prestasi, 1(1), 31-33. https://doi.org/10.24114/jp.v1i1.6495

Sovensi, E. (2018). Ketepatan Smash Pemain Bolavoli Siswa Sma Ditinjau Dari Koordinasi Mata-Tangan Dan Extensi Togok. Gelanggang Olahraga: Jurnal Pendidikan Jasmani Dan Olahraga, 2(1), 129-139.

Sugiyono. (2011). Metode Penelitian Kuantitatif, Kualitatif dan $R \& D$. Bandung: CV AlFABETA.

Heriyanto, L. (2016). Pengaruh Latihan Variasi Menendang Ke Berbagai Sasaran Untuk Meningkatkan 